\title{
Making the Dream of a Sámi School Come True: Voices from the Field
}

\author{
Kaarina Määttä \\ University of Lapland, Rovaniemi, Finland \\ Pigga Keskitalo \\ Sámi University College, Kautokeino, Norway \\ Satu Uusiautti \\ University of Lapland, Rovaniemi, Finland
}

\begin{abstract}
The development of the Sámi's own schooling system has been hindered by the history of assimilation, colonialism, and power relations. In Finland, there is no model of an independent Sámi School that is based on the $S$ ámi culture. In this artide, opinions of the experts of $S$ ámi education $(N=64)$ on the model of a possible Sámi School and its core obstacles and methods of development are introduced. The data were collected through individual writings and group discussions. Sámi education should hold a more autonomous position and it should have a special Sámi curriculum where the Sámi language would have a central role. The macro level of education should be developed so that sovereign Sámi education could be realized. An attitudinal change is also called for in order to perceive the importance and special nature of Sámi education. A model of a Sámi drum that strengthens the position of Sámi education is introduced as the conclusion.
\end{abstract}

Index Terms -Sámi education, Sámi pedagogy, cultural sensitivity in education, $\mathrm{S}$ ámi teachers, indigenous culture, indigenous teachers

\section{INTRODUCTION}

The first national Sámi Pedagogy Conference was held in Inari, Finnish Lapland, in 8-9 December 2011. The conference was organized by units that provide Sámi research and education: University of Lapland, Regional State Admin istrative Agency of Lapland, The Sámi Education Institute and Giellagas Institute. The purpose was to gather Sámi-speaking teachers and educational authorities of the Sámi administrative district and discuss the connection between research and education. The aim was to listen to experts of Sámi education and try to figure out means to support their role and to develop pedagogical methods in Sámi teaching. This article includes analyses of schooling questions in the field of Sámi education in Finland but the issue as such is of importance for indigenous peoples' possibilities to develop their culture sensitive teaching based on their own circu mstances.

This article is a part of the authors' joint project that aims at developing northern teacher education and which is a part of the Love-based leadership - interdisciplinary approach research project (see University of Lapland, 2011). Kaarina Määttä works as the professor of educational psychology at the University of Lapland and has supervised dozens of doctoral theses, including Pigga Keskitalo's and Satu Uusiautti's theses. University of Lapland provides teacher education and one of the strategic emphases of the university is the northern dimension as the strength. Dr. Keskitalo has worked in the field of Sámi teacher education, in Kautokeino, Norway, for years. She is a Sámi teacher and researcher interested in developing culturally relevant education. Dr. Uusiautti works as a post-doc researcher at the University of Lapland and her special field is in human strengths and positive strategies that enhance human well-being at various areas of life. As a research group, we form a team of experts who share a desire to create models that could further development of teaching and education. Educational research supports intercultural dialogue that we wanted to participate in through writing back together idea. It is important to share the information with the commun ity — both the mainstream society and the Sámi co mmunities - through scientific research.

Indigenous cultures, languages and ways of life are under constant threat of discrimination and lack educational opportunities. Giving voice to experts of indigenous peoples' education is important when aiming at promoting development that respects indigenous peoples' values and traditions. We support the idea that the aim of educational research is to support and protect human rights and fundamental freedom and right to pursue social and economic development.

\section{THE PRESENT ST ATUS OF SÁMI EDUCATION}

The Sámi form a heterogeneous group of approximately 70,000-100,000 people (depending on the method of assessment) who share linguistic ties and some cultural features. The Sámi live in a wide area called Sápmi which 
means the geographical area populated traditionally by the Sámi. The Sámi residential area expands to the northern regions of Norway, Sweden, Fin land, and the Kola Peninsula of Russia, and the border area between south and middle Sweden and Norway. At the mo ment, nine different language groups are left in the Sámi reg ions of the Nordic countries and Russia. The Sámi languages are categorized as endangered (Magga et al., 2005).

The Constitution of Fin land section 17 says that the Sámi, as an indigenous people, as well as the Roma and other groups, have the right to maintain and develop their own language and culture. Provisions for the Sámi's right to use the Sámi language with authorities are laid down by an act in the Sámi domicile area and in court and with other authorities. Enontekiö, Inari, northern Sodankylä (Vuotso area), and Utsjoki municipalities form the Sámi domicile area in Fin land (Constitution of Fin land, 1999; see Figure 1).

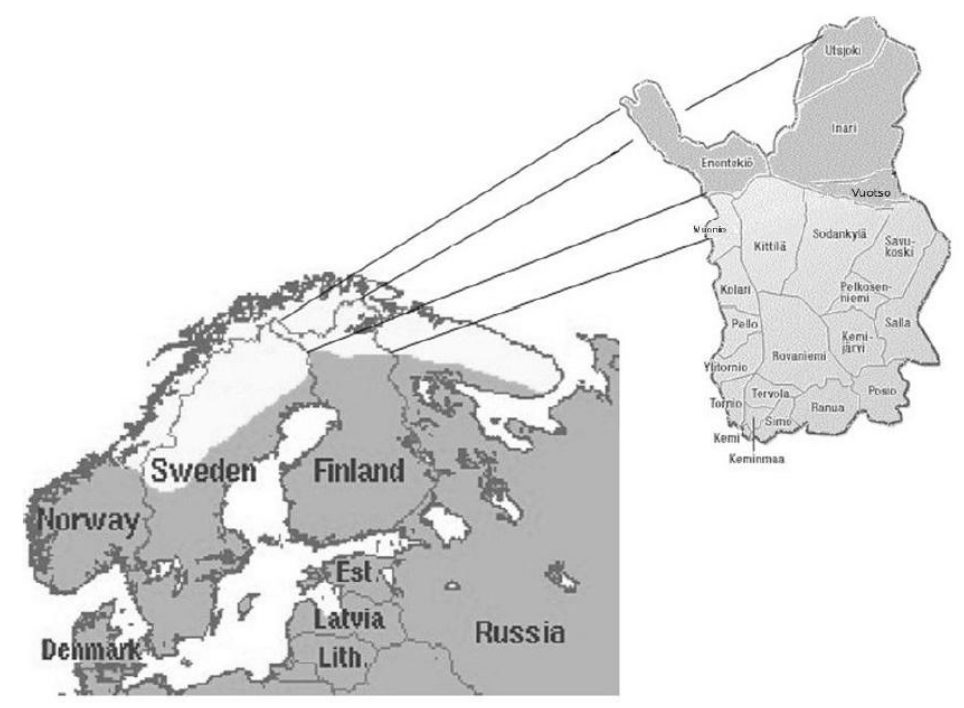

Figure 1. The Sámi domicile area in Finland and its neighboring countries.

Of the countries with a Sámi population, Norway has developed Sámi education the most. In the Sámi admin istrative district of Norway, the Sámi have a special Sámi comprehensive school that follows a Sámi curriculum with the emphasis on the idea of multicultural, integrated school. In Fin land, Sámi education is organized so that schools follow the national Finnish curriculum and Sámi children study together with Finnish children in the same schools. Separate Sámi grades are arranged in the Sámi domicile area. Sámi children are taught the Sámi language for two hours a week outside the Sámi domicile area. Yet, about $75 \%$ of under-10-year-old Sámi-speaking child ren live outside traditional area and lack proper support and strong pedagogy for their native language.

\section{METHODS}

The data were obtained at the Sámi Pedagogy Conference among people who work with Sámi education. The participants of the research $(\mathrm{N}=64)$ participated in the conference and were asked to share their e xperiences of Sámi education. The participants were teachers from the schools and daycare centers of the Sámi domicile area, local school authorities and representatives of the Finnish and Norwegian Sámi Parliaments and higher education. In this article, we call them experts of Sámi education just to have a common name for the participants of the research.

This article answers two main questions:

(1) What are the most salient disincentives to the realization of Sámi pedagogy in the opinions of the experts of Sámi education?

(2) How could the originality of Sámi pedagogy be furthered according to the perceptions of the experts of Sámi education?

Adhering to the abovementioned research questions, the empirical data were obtained in three phases. The participants first answered the first question by listing factors that they thought that could hinder or impede the realization of Sámi pedagogy. The participants were asked to write as many-sided and ample list as possible. Factors from the questionnaires were grouped by the researchers after which the second data were gathered through group interviews: the participants were divided into groups of 6-10 that were asked to discuss the second research question, the means of removing the obstacles of the realization of Sámi pedagogy. At the third phase, groups introduced their discussions to other conference participants and the plenary speakers summed up the themes.

Research involving indigenous people is being undertaken by researchers, who bring forward worldviews that shape the approach of the research, the theoretical and conceptual frameworks, and the epistemology, methodology, and ethics Many times such research bridges western practices and indigenous knowledge; however, bringing together these two worldviews can also present challenges. It might be challenging to find a way of bringing together Indigenous ways of knowing and western ways of conducting research, specifically qualitative inquiry. (Lavallée, 2009.) We try to meet 
this challenge as a research team that consists of both indigenous and non-indigenous researchers. We as researchers are aware of our position and want to show humble respect for this task. Yet, we want to share our experiences and expertise to develop the field through our collaboration. Simultaneously, we are aware that there are educational developmental projects going on in each country with a Sámi population. We want to contribute to this discussion and to the growing scholarly work of bridging indigenous ways of knowing and western prin ciples (see Smith, 1999).

We applied here the qualitative content analysis method with emphases on taking account indigenous research framework (see Smith, 1999). The results from individual writings and group discussions were transcribed. The data were analyzed with qualitative methods: qualitative content analysis was applied to categorize the data into themes that emerged from the answers, such as lack of teachers or the influence of the national curriculum as disincentives and cultural-sensitive teaching arrangements and the Sámi curriculum as factors that promote Sámi education. Finally, the results were put together and illustrated in the form of a Sámi drum. Participants' writings varied from a 15-item list of problematic issues to a short list of five issues. The group discussions provided a holistic exposition of the second research theme.

Qualitative data come in the form of words rather than in numbers. The issue, then, is how these words were transformed into data analysis (Silverman, 2005). Because the form or the contents of the participants' lists and interviews, the most natural way of analyzing the data was inductive content analysis. The purpose of qualitative inductive content analysis is to describe the data verbally and to create a theoretical entity of the phenomenon.

As the data collection happened in a special situation, it is worth discussing some reliability issues. Participants could write their answers to the first research question anonymously without the fear of becoming recognized. In group discussion, individual viewpoints were not in that central role as the purpose of the groups was to bring out common perspectives on the developmental work.

Because of the special focus of the conference, the participants already had a certain bias. However, these participants were unquestionably experts who know the field, its problems and opportunities. Therefore, they seemed to be not only suitable but also quite a special and unique group of informants and their experiences were considered the most valuable. As far as we know, these Sámi educators' voices have not brought out before on this large scale in Fin land. The data collected among these participants make a significant add to the discussion about indigenous peoples' education.

\section{RESULTS}

\section{A. Disincentives to the Realization of Sámi Pedagogy}

The participants list included disincentives to the realization of Sámi pedagogy and they could be categorized into ten categories.

1) Economic resources

The learning material office of the Sámi Parliament is responsible for the learning material production in the Sámi language. The state subsidy covers teachers' hiring costs for the municipalities that provide Sámi-speaking teaching and the teaching of Sámi language in the Sámi domicile area. These municipalities get other state subsidies, too, and municipalities are responsible for the practical expenses of education such as acquisitions of teaching materials and other relative costs, such as excursions.

Many participants brought out that Sámi education requires resources and consequently also financial support. Being such a small and special target group, finding finance from the schools' and municipalities' pocket can be difficult. Participants' answers highlighted the need for two kinds of extra-resources: extra-investment to ensure the cultural content so that particular pedagogical practices could be changed at the teaching level and on the other hand, support and understanding is needed so that teachers could participate in further education. This was exp ressed, for example, as follows:

Municipal authorities do not always understand that Sámi education costs if the aim is to realize Sámi education within its own cultural context.

Distances are long and means of communication are often difficult. Collaboration with parents and other partners, such as extra resources in teaching personnel, causes extra-costs:

Co-operation with parents requires travelling and money.

If we are to exit the classroom, we need a ride, money, and permission.

Likewise, school heads', rectors', and teachers' actual train ing can be impeded by the lack of train ing appropriations. Usually, Sámi teachers' continuing training is free of charge. However, the municipalities normally have to cover teachers' travelling expenses.

2) Teachers' loneliness and isolation

Sámi teachers work often alone, far away, and apart. They have a huge responsibility to bear. Yet, the support they get at the school level varies. In this research, experts of Sámi education listed various measures of support that are needed: a forum where teachers could share experiences and a system that would support Sámi education in a holistic manner. 
Often, communication happens via internet but internet connections do not always work in schools nor can they compensate face-to-face meetings. In addition, teachers do not have time or resources to coordinate these measures of support by themselves but separate actions are needed.

Although we do have distance education, the network does not work in a sufficiently flexible way.

The lack of co-operation occurred at many levels from the school and municipal levels to the state and international levels. The field of Sámi education is relatively scattered, unorganized, and politically unstandardized. A political program for Sámi education is missing. In addition to the Saami Parliamentary Council, Norwegian, Swedish, and Finnish Saami Parliaments have entered developmental needs of Sámi education. However, any actual measures to harmonize educational is sues or practical co-operation at the comprehensive school level have not succeeded:

It would necessitate a great, revolutionary change in the whole school organization: every level, all the way from the director of education to teachers.

3) Bias and lack of information

To realize Sámi education adequately, a more positive attitude and more information about the special traits of Sámi education are needed. Many of the participants highlighted the importance of having a clear definition of Sámi pedagogy because otherwise it is not possible to implement it:

We do not have enough training to know what Sámi pedagogy is.

We should know what we mean by Sámi pedagogy, in other words we need training.

It is not enough that teachers are aware of the concept. The general attitude, support, and understanding are crucial as well. So me participants also expressed their concern about the lack of societal appreciation, prejudices, and even the envy of mainstream population.

It seemed that some people in schools and communities did not understand the meaning of positive discrimination for Sámi education. Resulting from assimilation, the Sámi have lost some of their linguistic and cultural special characteristics including their traditional knowledge system, and that has affected the economic-social well-being of individuals and communities. It takes time to remedy the situation. However, the extra support Sámi education needs is often denied at the municipal decision-making level or at school level by teachers:

Lack of general appreciation of Sámi pedagogy at school.

Due to lack of information, some people may consider Sámi education even a threat. Prejudices may be based on the more general disdain toward multicultura lis $m$ and multilingualis $\mathrm{m}$ :

Lack of pluralism. How to live in a pluralist manner?

Attitudes and strain from the environment: what knowledge/skills are important and appreciated?

4) Lack of qualified Sámi teachers

The number of Sámi teachers is low and most of them will retire in the near future. Many of the participants were concerned of the availability of qualified Sámi teachers:

Lack of skillful teachers, multiply skilled persons.

Lack of qualified Sámi-speaking teachers.

At the moment, Sámi-speaking teachers are being educated in many institutions. In Finland, there are special quotas for Sámi-speaking teacher students at the Universities of Lapland and Oulu. Norway has provided special Sámispeaking teacher training already since 1989. Otherwise, it is possible to have the Sámi language as a major in Oulu, Troms $\varnothing$, Norway, and Umeå, Sweden. Some studies in Sámi language are provided by the University of Helsinki, Fin land, as well.

5) Lack of Sámi pupils

Furthermore, there is lack of Sámi pupils and age groups are small. Often, their school commutes are very long. In addition, it is difficult to reach Sámi children who live in the southern Finland. On the other hand, teaching is not even always available. Therefore, they have not participated in Sámi education sufficiently.

Reaching Sámi children who live outside the Sámi domicile area is problematic because there is no system to remedy the problem.

Most of the Sámi-speaking child ren do not have Sámi-speaking teaching outside the official Sámi do micile area. The situation is extremely threatening for the continuity of Sámi language. Many generations are lost and proper revitalization measures have not been launched yet systematically and extensively enough.

6) The chains of the national core curriculum

In Finland, the national core curriculu m for comprehensive schools has been appraised even internationally. However, according to the participants in this research, it does not pay attention to the special traits of Sámi culture. Still, all schools are obliged to follow the national core curriculu m:

The control: laws and decrees control the Finnish school system that also the Sámi education has to follow.

Finns believe that the Finnish school is the best as is; they think that ifyou do not study along the Finnish model, you will not succeed.

Sámi teachers are between a rock and a hard place: even if they wanted to teach according to the principles of Sámi pedagogy, they would have to sacrifice the national core curriculu m.

Although the curriculum is meant to support and guide teaching, Sámi teachers regarded it as restricting. Likewise, the time for teaching is limited: 
There is not enough time to plan teaching alone and together.

Sámi education is often in a contradictory situation: which one is more important-Sáminess or realization of the obligatory curriculum?

7) Restricting and inflexible practical teaching arrangements

In this research, experts of Sámi education pointed out that teaching practices are based on the traditional Finnish classroom teaching which is usually teacher-led and organized into 45-minute-long lessons.

Time problem: the lesson is 45 minutes, 6 hours a day.

The culture of working along (1 teacher per classroom).

The Sámi's different conception of time cannot be implemented in the traditional lesson and semester model. Not only teacher colleagues but also pupils find it difficult to be flexible. Sámi model would have student-and task-oriented way of organizing lessons and breaks and semesters.

Too deep-rooted models control the school system too much.

The Finnishnized school - too much classroom teaching when we should design teaching together with all classes, in themes.

Time is bound to other teachers' lessons; we would need time for projects but they are difficult to realize because there are other subjects, e.g. English, and other teachers would not like that.

8) Lack of learning materials

There is not enough learning material in the Sámi language or it is old and not culturally relevant.

Lack oflearning materials in schools in all three [Sámi] languages.

Often, Sámi teachers prepare learning materials by themselves but they do not have enough time for all this. Similarly, there are no teachers' manuals in the Sámi language except for a few school subjects. Moreover, the problem in translated materials is their weak cultural basis. All in all, there is not enough material to support teaching, not enough producers of learning materials, or work force to adjust the existing materials to Sámi pedagogy:

Lack of ancillary staff.

Overall, the school provides little information about the Sámi.

9) Lack of the Sámi language proficiency

Language is the foundation of teaching and culture. If there are no Sámi speakers, the whole Sámi pedagogy is shaken.

There is lack of qualified Sámi-speaking subject teachers. Pupils' language proficiency varies greatly and parents do not necessarily speak the Sámi language at home or with other relatives. Sámi families' language policy can be partly undefined because of the history of assimilation.

According to the act of education, only part of education is provided in the Sámi language and that is too little.

There is no Sámi School in Finland (although there should be). There is just the Finnish School.

10) The Sámi's insecurity

Many of the participants recognized their own responsibility as promoters of Sámi education but were ins ecure. And yet, without the Sámi people selves being active and setting the example, Sámi education cannot strengthen:

The feeling that I cannot realize it (what if I hurt the children in case I cannot act in the right way).

You could trust in your own Sáminess and want out Finnishness that affects everything, even your thoughts. You should dare to be Sámi at your work place as well.

Moreover, teachers' activity is not enough but parents and children have to participate. Without their participation, teachers have too many responsibilities to bear:

Parents do not participate in school activities.

\section{B. Means to Strengthen Sámi Pedagogy}

The participants were asked to discuss how to strengthen Sámi education. Their practical experiences, thoughts, and ideas were categorized into four partly overlapping groups.

1) Positive attitudes and resources

Positive attitudes toward Sámi pedagogy were considered a salient factor in the realization of Sámi education. According to group discussions, Sámi pedagogy should become appreciated by the school community and also wider in the society.

The school administration should commit to Sámi pedagogy so that Sámi teachers were not left alone when implementing teaching.

The participants of this study highlighted that the arousal of positive attitudes necessitates knowledge of Sámi pedagogy. Schools should provide in-service and continuing education in Sáminess and its educational special traits. Sámi teachers are true mu ltiple skilled people who should also be recruited as prospective teachers' in-service educators and learning material producers.

Certain practical means could promote positive attitudes, too. Sáminess could be brought out in a positive manner in theme days at school and for example, the Sámi national day could be celebrated and consciously highlight Sámi culture in an appreciative way.

In Inari, they presented a Sámi-speaking Christmas play in which all 1 and 2 -graders participated and at least pupils did not see any problem in it. 
Sámi education should not be spared.

2) A Sámi curriculum and the Sámi language

It was considered essential to create and implement a Sámi curriculum where the Sámi language has a central role. The curricu lu m cannot just be an application of the Finnish curriculu m but it should be based on the Sámi's premises.

The core principle of curricu lum design should be equality and parity. Sámi children should have the same rights to have education that is based on their own culture than other child ren have-and equality should not be used against Sámi children:

As the dominant language at school is Finnish, Sámi children remain a minority.

We need a totally separate and own Sámi School.

3) Cultural-sensitive teaching arrangements

According to the data, Sámi teachers among other experts of Sámi education wanted to wreck stereotype conceptions or prejudices concerning Sámi children's background or future.

Not all Sámi people are fishermen or reindeer herders.

Traditional livelihoods are plied also as compound livelihoods, for example together with touris $\mathrm{m}$ and other service industry. The proportion of natural livelihoods in revenue and workforce is not very large but the cultural meaning is significant. They are not just livelihoods or professions but parts of a unique life style. So me of the Sámi still ea rn their living in traditional livelihoods but a considerable proportion of the Sámi work in modern professions (Saami Parliament, 2008). Still, the old myths seem to hinder the development also in the Sámi's own cultural context.

The Sámi conception of time, place, and knowledge necessitates a breakaway from the Finnish teaching practices. Even the smallest details make a good example:

The classroom curtains could illustrate Sámi craftsmanship and colors.

The school decoration could exploit traditional handicrafts (Sámi national dresses, guksi- carved birch drinking cup, Sámi knives, jewelry, tools, drums, decorations, etc.) that everyone had to be able to prepare previously. Pupils' handicrafts should be laid out as it also increases pupils' motivation at school (see Pollack \& Shuster, 2001). The Sámi construction culture and seasons were previously tied to their nomadic living style and hunting culture. It can also be taken into account in teaching arrangements:

Pupils should be able to spend time in a tepee by the fire, do things that are part of Sámi culture and learn new.

All this should happen through a holistic educational idea rather than offering just singular parts of Sámi culture. The Sámi group is small and therefore, new practices should be developed to make teaching more integrated and stable. It would be important to try new approaches - a sort of pedagogical revolution:

Why could you not teach math and handicraft simultaneously?

...nor would Sámi classes be forced to beg money for handicraft materials.

4) The ideal Sámi School

The participants described their idea of an ideal Sámi School where everyone would speak the Sámi language and their language proficiency would be furthered through constant usage:

There would be leaming materials and various stages and levels to enhance language proficiency.

This school would be everyone's school and "not a lonely island". The school would support Sámi families and strengthen the family-centeredness which is typical of the Sámi culture. Thus, the school would support the Sámi's story-telling tradition that would transmit traditions from one generation to another:

There would be a day care center and a retirement home with the school premises.

Likewise, the principles of peer learning, joint learning and action could be reinforced:

Older pupils could guide the younger ones-and learn something new themselves.

Togetherness, trust, appreciation, and responsibility for various school tasks would enhance pupils' positive selfimage and be based on the Sámi story-telling tradition. Consequently, school premises and physical environment would be molded to represent the Sámi culture. The connection with nature should be preserved and thus, nature education and "night schools" would support the understanding of nature - the nature has offered the setting for life and livelihoods.

What would be the physical environment - there would not be a school building but an eternal camping school.

Everyone should share the knowledge and understanding about the objectives and goals of school and education and all this would result in the well-being of Sámi culture and Sámi children:

... so that the child would do well and have a strong self-esteem.

\section{CONCLUSIONS}

The conference participants' answers showed that the core of the Sámi School is to secure the Sámi language and the Sámi language teaching. In addition, it is important to strengthen the special characteristics of the Sámi culture and the contents of the Sámi pedagogy that are drawn from the culture (see also Darnell \& Hoëm, 1996). Instead of providing singular pieces of the Sámi culture, the Sámi School is an entity and its values and operation are based on the Sámi values and way of thinking and the needs of the Sámi community and the multicultural society.

These research results correspond to the recent publications that have brought out epistemological questions about research on indigenous peoples as well as special questions about rearing and education (e.g. Aikio -Puoskari, 2005; Balto, 2008; Hirvonen, 2004/2003; Kuokkanen, 2007; Smith, 2005). Studies on indigenous peoples' teaching and 
education around the world seem to elicit information that concerns our research as well (see Darnell \& Hoëm, 1996; Lipka et al., 1998).

Furthermore, this study proves the need for the creation and realization of the Sámi School system toward the similar direction with the ones in Norway and Sweden. According to Rauna Kuokkanen (2000), indigenous peoples' education necessitates paradigmatic change that alters the theory of knowledge and methods of acquisition of information toward the holistic nature that is typical of indigenous peoples. This requires the context where the cultural and linguistic reality at school is taken into consideration.

Based on the perceptions from the field, we designed a model, a Sámi education developmental drum (see Figure 2) adopted from the Sámi culture. This drum symbolizes a thought that it is about the time to develop Sámi pedagogy, to use the drum for the Sámi-speaking Sámi education. All Finnish Sá mi drums represent a three-dimensional worldview: upper, middle, and lower worlds. First they had transcendental meanings but later on more practical ones. Here, the drum also has three worlds. The Sámi language is located in the middle as it is considered the most important factor. Other significant features represent teaching and other practical is sues taking place at school while the third dimension covers societal environment and conditions.

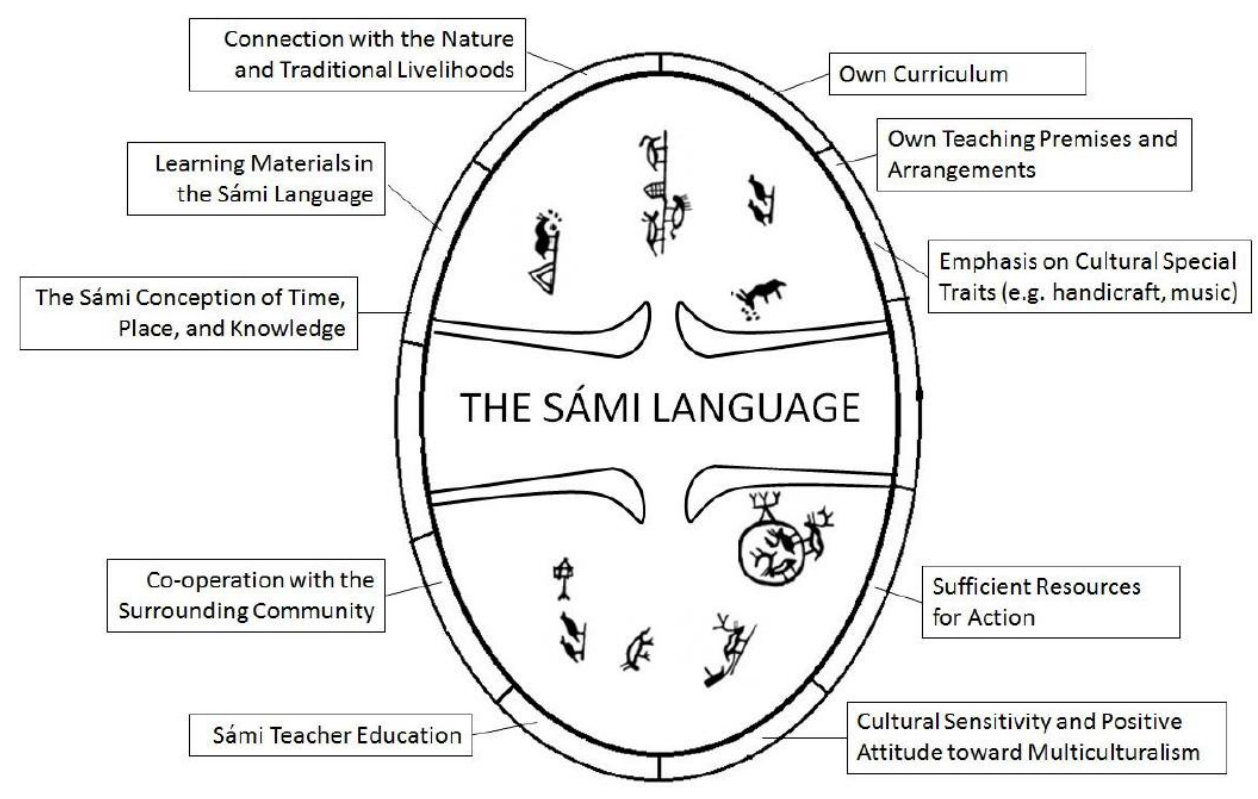

Figure 2. The developmental drum of Sámi education

Language is one of the most significant factors of identity and its importance cannot be undermined when discussing the future of the Sámi as an indigenous people (Keskitalo \& Määttä, 2011c). Thus, it is placed in the center of the model, in the middle world. In Finland, pupils who speak the Sámi language are taught mainly in the Sámi language. This wording may lead to a decrease in the Sámi language teaching among the decreasing number of Sámi pupils. In order to avoid the extinction of the Sámi language, strengthen its development and avoid language change and assimilation trends, teaching in one's native language should be guaranteed at every school level unequivocally. Furthermore, it is important to promote positive attitudes toward indigenous peoples among other populations. At the Sámi School, the Sámi language would be the teaching language of every school subject. Naturally, it is the question of economic investments, too: the organization of Sámi education should be financially supported even when provided outside the Sámi domicile area.

The sustenance and development of language nest and language immersion methods are crucial when aiming at strengthening the Sámi language (see also Keskitalo, Määttä, \& Uusiautti, 2011; 2012). They are important but need to be accompanied with language revitalization (see Sarivaara, 2012). Sámi language courses should be arranged as inservice training so that employees' ability to speak and write in the Sámi language would improve and simultaneously they would appreciate their own language more.

The school level, the upper world in the drum, includes special school-level arrangements. In order to not lose out to the Finnish language and the Finnish curriculum and school system, the Sámi School needs a curriculum, teaching premises and arrangements, and Sámi learning materials of its own. The Sámi selves have to be active and highlight the necessity of strengthening their own culture within school practices. Thus, their own history and knowledge about the modern Sámi community, Sámi craftsmanship (duodji), Sámi art, music (luohti, leu’dd) and story-telling tradition (máinnas) have a central role. The connection with the nature, the coexistence of the human being with the nature and traditional livelihoods is important. It means that reindeer pasturage, fishing waters, courses, small-scale agriculture, picking culture and handicrafts are considered a part of cultural knowledge. The question is about appreciating cultural capital in schools (see Yosso, 2006). 
Likewise, the Sámi conception of time, place, and knowledge can mold the realization of teaching (Keskitalo, 2010; Keskitalo \& Määttä, 2011b). Pupils should be provided with positive experiences related to their own culture through play, story-telling, action, and participation. Teaching should be adjusted with the yearly cycle of the local Sámi community, traditional seasonal work and changes that take place in the nature (Rasmus, 2004). If pupils cannot participate in reindeer herd ing and seasonal activities related to it (e.g. reindeer roundup) or if they are not allowed to see items that represent the Sámi culture, handicrafts, art, or other objects, at school, they will not learn to appreciate their cultural heritage (see also Chacón, Yanez, \& Larriva, 2010).

The central task of the school is to support the Sámi pupils' identity: the school must provide chances to the development of a healthy self-esteem so that the Sámi pupils can have their Sámi identity without assimilation in the mainstream population (Keskitalo, Määttä, \& Uusiautti, 2012).

To sum, it is necessary to take action to rationalize teacher education (cf. Cuban, 1993), strengthen virtual education, and create language revitalization programs. Consequently, the third world in the drum represents the overall cond itions that make the Sámi education possible.

Sufficient economic resources are needed to start the action. Sámi-speaking teacher education should pay special attention to the teaching methods suitable for teaching pupils with various linguistic backgrounds, to the forms of highlighting the Sámi culture, and to the problems of minority cultures. This kind of extra training should be arranged in the Sámi do micile area when it would be possible to participate in the training alongside work without hig h expenses (cf. Näkkäläjärvi \& Rahko, 2007). Natural providers of education would be the Sámi Univers ity College (Kautokeino, Norway), Sámi Education Institute (Inari, Finland), University of Lapland (Rovaniemi, Finland), and Giellagas Institute at the University of Oulu (Oulu, Finland) —in collaboration. Likewise, early childhood education needs Sámi-speaking early childhood educators and preschool teachers.

The starting point of Sámi education is challenging compared to the mainstream culture because it does not have all the material and support that are normally provided for language teaching. Actually the worldview differs from the mainstream culture insomuch that knowledge about learn ing should be constructed from a new point of view. Teachers' in-service training could seize on this situation. Teachers should be informed of indigenous educational practices. Indeed, according to Barbara Seidl and Gloria Friend (2002) "the development of sophisticated, culturally relevant pedagogies is a process that requires commitment over tie and lived experience" (p. 427).

Because most of the Sámi children live outside the Sámi domicile area, it would be important to develop virtual education and provide necessary personnel and material resources to implement it. The Sámi Education Institute has already started this work.

In addition, the results suggest that co-operation with the wider Nordic community is valuable both to Sámi teachers and pupils. Teaching should support pupils' identify with their national cultural heritage and their sense of solidarity with the Sámi people who live in different countries (see also Cajete, 1994). Respect for the Sámi culture means also respect for multiculturalis m (see also King \& Schielmann, 2004; Macfarlane, 2004). Indeed, Sámi education could get new stimuli from the cultural sensitive education in North-America and New Zealand where students' culture and experienced are given emphasis (e.g. Kirkeness, 1992; 2003; Lipka et al., 1998; Macfarlane, 2004). For example, the community elders take part in education as the bearers and transmitters of culture (Stiegelbauer, 1996). The aim is to enculturate children in the surrounding culture.

\section{DISCUSSION}

It was not until the 1970s when the Sámi education took root in school and the Sámi's own opinions were taken into account in educational planning since the missionary period (Aikio-Puoskari, 2005) - partly due to the awakening of Sáminess and the Sámi's political rise. Our study showed that many things should still change to make the Sámi School reform according to the guidelines that the participants of the conference talked about. Is this kind of a change possible? The school system is guided by world-wide economic, political, and social tensions: schools have become places where teachers and pupils are controlled, supervised, compared, and considered liable for their action (see Youdell, 2011).

There are many theoris ts whose ideas encourage us to interfere in today's educational practices, shake inequality and dissolve ideas of normative knowledge, meanings, and subjects. Let us mention Gilles Deleuze and Félix Guattari's (1987) concepts of the as semblage, becoming, and rhizo matics. Michel Foucault's (e.g. 1982) writings about resistances, practices of the self, and parrhesia/fearless speech and Judith Butler's (1997) thoughts about performative politics, discursive agency, and collectivities. At times, these concepts seem arcane but their purpose is to introduce ways of interfering or question the prevailing "normality" of the school. Besides, Deleuze and Guattari noted that they do not even want to become understood but actually misunderstood!

Education is one of the most powerful state structures that instill and renew the dominant ideology. Education and rearing have conscious and unconscious influence on us. Education does not teach just practical skills, such as reading and math, but e mbeds societal moral rules, norms, and culture that teach how to speak and think right (see Hier, 2003). Consequently, it is possible to look for optional phrasings of question and challenge normative interpretations and ideologies. Indeed, unspoken viewpoints in the field of education and rearing belong to this category as well. If become informed of these issues, we are aware and realize what kinds of appreciations, practices, models, hidden effects, 
resources, and social re lationships are included in the daily schooling. At its best, awareness leads to critical discussions and enables us see new perspectives.

In order to develop the Sámi School, it is necessary to listen to the active realizers of Sámi education, namely Sámi teachers. Not only do they have plenty of tacit knowledge but also "conscious silence" that we have to listen to and take into account when aiming at strengthening Sámi pedagogy. At the Sámi teachers' ideal school, premises are open, accessible and welcome to everyone; a place where everyone listens, hears, discusses; where teachers have time and interest in pupils' ideas, thoughts, experiences, feelings, fantasies, and hopes; where mutual trust between various generations and genders is present; where the conception of knowledge and knowing has new forms; and where experiential and communal learning are given space (cf. Youdell, 2011). The ideal school is the one where cultural sensitivity and policies are recognized and acknowledged and which strengthens the cultural identity of its me mbers.

The Sámi culture has already seen glimpses of this kind of a school and therefore educational researchers and developers should not give up on looking for a better education. We want to provide starting points for a discussion that would hopefully lead to the more positive utilization of aspects of Sámi culture in the education system in Finland, and perhaps, it would contribute to the similar discussion in the whole indigenous world. The dream of a Sámi School and Sámi pedagogy is realistic.

\section{REFERENCES}

[1] Act of 12 June 1987/56 concerning the Sameting (the Sami parliament) and Other Sami Legal Matters (the Sami Act). Regjeringen. http://www.regjeringen.no/mobil/en/doc/laws/Acts/the-sami-act-.html?id=449701 (accessed 13/8/2012).

[2] Aikio-Puoskari, U. (2005). The Education of the Sámi in the Comprehensive Schooling of Three Nordic Countries: Norway, Finland and Sweden. (Gáldu pála 2/2005.) Guovdageaidnu: Resource Centre for the Rights of Indigenous peoples.

[3] Balto, A. (2008). Sámi oahpaheaddjit sirdet árbevirolaš kultuvrra boahttevaš buolvvaide: dekoloniserema akšuvdnadutkamuš Ruota beale Sámis [Sámi teachers transforming traditional culture to the next generations: action research about decolonization in Sápmi in Sweden]. Guovdageaidnu: Sámi allaskuvla.

[4] Butler, J. (1997). Excitable speech: a politics of the performative. London: Routledge.

[5] Cajete, G. (1994). Look to the mountain: an ecology of indigenous education. Duran go: Kivaki Press.

[6] Chacón, H., F. Yanez \& G. Larriva. (2010). Ecuadorian Amazonian cultures: theoretical approaches to the training of researchers. In J. C. Llorente, K. Kantasalmi \& S. J. de Dios (eds.), Approaching indigenous knowledge. Complexities of the research process. Helsinki: University of Helsinki, 47-68.

[7] The Constitution of Finland. (731/1999). Ministy of Justice. Finlex data base. Available from: http://www.finlex.fi/fi/laki/kaannokset/19999/en19990731.pdf (accessed 28/6/2011).

[8] Darnell, F. \& A. Hoëm. (1996). Taken to extremes: education in the far north. Oslo: Scandinavian University Press.

[9] Deleuze, G. \& F. Guattari. (1987). A thousand plateaus. Minneapolis, MN: University of Minnesota Press.

[10] Foucault, M. (1982). The subject and power. In H. L. Dreyfus \& P. Rabinow (eds.), Michel Foucault: Beyond hermeneutics and structuralism. Brighton: Harvester, 208-226.

[11] Hier, S. P. (2003). Probing the surveillant assemblage: on the dialects of surveillance practices as processes of social control. Surveillance and Society 1.3, 399-411.

[12] Hirvonen, V. (2004/2003). Sámi culture and the school: reflections by Sámi teachers and the realization of the Sámi School. An evaluation study of Reform 97. Karasjok: ČálliidLágádus.

[13] Keskitalo, P. (2010). Saamelaiskoulun kulttuurisensitiivisyyttä etsimässä kasvatusantropologian keinoin [Cultural sensitivity in the Sámi school through edu cational anthropology]. (Dieđut 1/2010.) Guovdageaidnu: Sámi allaskuvla.

[14] Keskitalo, P. \& K. Määttä. (2011a). Sámi pedagogihka iešvuođat / Saamelaispedagogiikan perusteet / The Basics of Sámi Pedago gy / Grunderna i samisk pedagogik / Основы саамской педk. Rovaniemi: Lapland University Press.

[15] Keskitalo, P. \& K. Määttä. (2011b). How Do the Sámi Culture and School Culture Converge - or Do They? The Australian Journal of Indigenous Education 40, 112-119. doi: 10.1375/ajie.40.112.

[16] Keskitalo, P. \& K. Määttä. (2011c). The Linguistic Special Features of the Sámi Education. Indian Journal of Applied Linguistics 37, 5-26.

[17] Keskitalo, P., K. Määttä \& S. Uusiautti. (2011). Toward Practical Framework of Sámi Education. British Journal of Educational Research 1, 84-106.

[18] Keskitalo, P., K. Määttä \& S. Uusiautti. (2012). Sámi Education in Finland. Early Child Care and Education in Fin land 182.3-4, 329-343. doi:10.1080/03004430.2011.646723.

[19] King, L. \& S. Schielmann. (2004). The challenge of indigenous education: practice and perspectives. Paris: Unesco.

[20] Kirkeness, V. J. (1992). First nations and schools: triumphs and struggles. Toronto: Canadian Education Association.

[21] Kirkeness, V. J. (2003). Aboriginal Education in Canada: a retrospective and a prospective. In V. Hirvonen (ed.), Sámi áddejupmi ja sámi skuvla. Davviriikkalaš sámi skuvladutkiid konferánsa Guovdageainnus 7.-9.11.2001 [Sami understanding and Sami education. Nordic Sami Educational Research Conference Kautokeino November 7th-9th 2001]. Guovdageaidnu: Sámi allaskuvla, 51-65.

[22] Kuokkanen, R. (2000). Towards an "Indigenous Paradigm” from a Sami perspective. The Canadian Journal of Native Studies 20.2, 411-436.

[23] Kuokkanen, R. (2007). Reshaping the university: responsibility, indigenous epistemes, and the logic of the gift. Vancouver: UBC Press.

[24] Lavallée, L. F. (2009). Practical application of an indigenous research framework and two qualitative indigenous research methods: sharing circles and Anishnaabe sy mbol-based reflection. International Journal of Qualitative Methods 8.1, 21-40.

[25] University of Lapland. (2011). Love-Based Leadership - Interdisciplinary Approach. http://www.ulapland.fi/?deptid=23029. (accessed 22/6/2012). 
[26] Lipka, J., G. V. Mohatt \& the Ciulistet Group (eds.) (1998). Transforming the culture of schools. Yup'ik eskimo examples. Mahwah: Lawrence Erlbaum Associates.

[27] Magga, O. H., I. Nicolaisen, M. Trask, T. Skutnabb-Kangas \& D. Robert. (2005). Indigenous children's education and indigenous languages. Expert paper written for the United Nations Permanent Forum on Indigenous Issues. New York, NY: United Nations. http://www.tove-skutnabb-kangas.org/pdf/PFII_Expert_paper_1_Education_final.pdf (accessed 16/6/2011).

[28] Näkkäläjärvi, E. \& R. Rahko. (2007). Saamen kielen ja saamenkielisen opetuksen asema ja merkitys [The position and meaning of the Sámi language and Sámi-speaking teaching]. In S. Pöyhönen \& M.-R. Luukka (eds.), Kohti tulevaisuuden kielikoulutusta. Kielikoulutuspoliittisen projektin loppuraportti [Toward the future language education. The final report of the project of language educational policy]. Jy väskylä: University of Jy väskylä, 253-274.

[29] Pollack, W. S. \& T. Shuster. (2001). Real boys' voices. New York, NY: Pen guin Books.

[30] Rasmus, E.-L. (2004). Saamelaisen identiteetin merkitys Utsjoen nuorille. Kasvatusantropologinen tutkimus saamelaisten maailmankuvasta ja identiteetistä [The Sámi identity and its meaning for the Sámi youth in Utsjoki. Educational Anthropological research about worldview and identity of the Sámi people]. Rovaniemi: University of Lapland.

[31] Saami Parliament. (2008). Saamelaisten kulttuuri-itsehallinto opetustoimessa. Saamelaiskäräjien perusopetusta ja lukiokoulutusta koskevat koulutuspoliittiset tavoitteet [The Sámi's cultural self-government in education. Educational political goals of the Saami Parliament regarding basic and high school education]. http://www.samediggi.fi/vanha/oktavuohta/kulttuuriitsehallinto.doc (accessed 20/6/2012).

[32] Sarivaara, E. K. (2012). Statuksettomat saamelaiset. Paikantumisia saamelaisuuden rajoilla [Non-Status Sámi. Locations within Sámi Borderlands]. Kautokeino: Sámi University College.

[33] Seidl, B. \& G. Friend. (2002). Leaving authority at the door: equal-status community-based experiences and the preparation of teachers for diverse classrooms. Teaching and Teacher Education 18, 421-433.

[34] Silverman, D. (2005). Doing qualitative research: A practical handbook. London: Sage.

[35] Smith, L. T. (1999). Decolonizing methodologies: research and indigenous peoples. London: Zed Books.

[36] Smith, L. T. (2005). Building a research agenda for indigenous epistemologies and education. Anthropology and Education Quarterly 36.1, 93-95.

[37] Stiegelbauer, S. M. (1996). What is an elder? What Do Elders Do? First nation elders as teachers in culture-based urban organization. The Canadian Journal of Native Studies 1, 37-66.

[38] Youdell, D. (2011). School trouble. identity, power and politics in education. London: Routledge.

[39] Yosso, T. J. (2006). Critical race counterstories along the Chicana/Chicano educational pipeline. New York, NY: Routled ge.

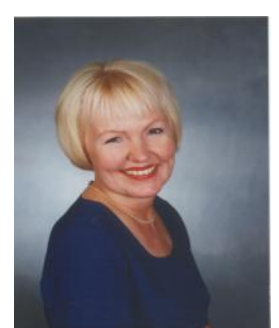

Kaarina Määttä (Hämeenlinna, Finland, 14 October 1951). Määttä graduated as Master of Education, University of Jyväskylä, Jyväskylä, Finland in 1974; Class Teacher Certificate, University of Jyväskylä, Jy väskylä, Finland, in 1975; Licentiate of Education, Univers ity of Lapland, Rovaniemi, Finland, in 1985; and Ph.D. (education), University of Lapland, Rovaniemi, Finland in. 1989.

She works currently as Professor of Educational Psychology at the Faculty of Education, University of Lapland is also Vice-rector of the University of Lapland, Rovaniemi, Finland. Her most important posts are Docent of Teacher Education, Faculty of Art and Design, University of Lapland, 1.1.1991- (tenured); Professor (substitute) of Art Education, Faculty of Art and Design, University of Lapland, 1997-1998; Professor (substitute) of Education, Faculty of Education, University of Lapland, 1988-1996; Lecturer in Education, Special Education, and Didactics, Faculty of Education, University of Lapland, 1982-1987; Planning Officer of Curriculums and Studies, Administration office, University of Lapland, 1979-1982; Assistant of teacher education, Teacher Education Department in Rovaniemi, University of Oulu, 1977-1979; Teacher (classteacher in the elementary school), City of Äänekoski, 1975-1977; Research Assistant, Instruction of children with visual impairment, communication disorders, and deaf, University of Jyväskylä, funded by Finnish Academy, 1973-1974. Her latest books published in En glish are Obsessed with Doctoral Theses. Supervision and Support during the Disseration Process? (Rotterdam, Sense Publishers, 2012) and Keskitalo, P. \& Määtt ä, K. Sámi pedagogihka iešvuođat / Saamelaispedagogiikan perusteet / The Basics of Sámi Pedagogy / Grunderna i samisk pedagogik / Основы саамской педk (Lapand University Press, Rovaniemi, 2011). Her latest research interests cover love, affection, social relationships in life-span; mentoring and supervising of doctoral theses, process of doctorating; emotions and education; positive psychology in education and special education; and early education.

Prof. Määttäpositions of trust are; Vice-rector, University of Lapland; Dean of Faculty of Education, University of Lapland, 20022004, 2004-2006, 2006-2008; Chairperson of Scientific board, Faculty of Education, University of Lapland, 2004 -; Vice-Dean of Faculty of Education, University of Lapland, 2000-2002; Member of Government of University of Lapland, five periods since 1979; Chairperson and member of Faculty Council, Faculty of Education, University of Lapland, five periods since 1992; Member of Teaching council of University of Lapland, 2007 -; Member of Advisory board, Centre for Research Education, 2007 -; Director of Teacher Training Department, Faculty of Education, 2000-2002.

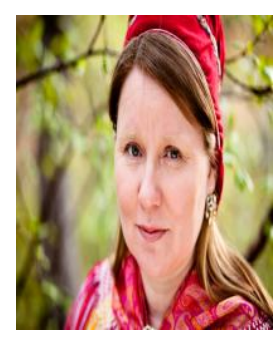

Pigga Keskitalo (Utsjoki, Finland, 18 August 1972). Keskitalo graduated as Master of Education, University of Lapland, Faculty of Education, Finland, in 1997; Licentiate of Education, University of Lapland, Faculty of Education, Rovaniemi, Finland in 2008; and Doctor of Education, University of Lapland, Faculty of Education, Rovaniemi, Finland, in 2010. She is a Sámi woman herself and the Sámi langu age is her mother tongue. She has got three Sámi speaking children with her husband who works as a reindeer herder in EastEnontekiö area in Finland.

She works currently as Associate Professor at the Sámi University College, Guovdageaidnu, Norway, where she has been working also as a lecturer, doctoral scholarship student and researcher. Her personal 
research interests are in indigenous methodology, Sámi teaching and Sámi language didactics, Sámi knowledge, Sámi curriculum, Sámi teacher training etc. She has published many peer-reviewed international articles. Her doctoral thesis is about Sámi education and how it succeeds in practice. She has published a book about Sámi education together with Professor Määttä Keskitalo, P. \& Määttä, K. 2011. Sámi pedagogihka iešvuođat / Saamelaispedagogiikan perusteet / The Basics of Sámi Pedagogy / Grunderna i samisk pedago gik / Основы саамской педk. (Lapland University Press, Rovaniemi).

Dr. Keskitalo is Member of Finnish Educational Research Association, 2012 - and Member of a few Editorial in international, peer-reviewed journals.

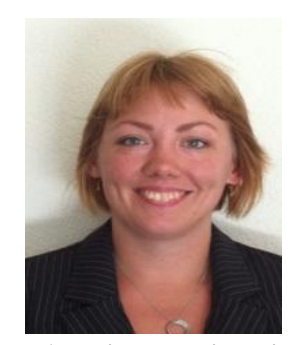

Satu Uusiautti (Sura, Sweden, 31 October 1980). Uusiautti graduated as Master of Education, University of Lapland, Faculty of Education, Rovaniemi, Finland, in 2003; Licentiate of Education, University of Lapland, Faculty of Education, Rovaniemi, Finland in 2007; and Doctor of Education, University of Lapland, Faculty of Education, Rovaniemi, Finland, in 2008.

She works currently as Post-doctoral Researcher at the University of Lapland, Rovaniemi, Finland. Her most important posts are Planner/researcher, University of Lapland, Rovaniemi, Finland, 2011; Freelance educator, translator, and language consultant (CEO), S. Uusiautti Ltd., 2010 - ; Research Assistant, NationalLevel Coordination Project of Degree Program Development in Teacher Training and the Sciences of Education (VOKKE), University of Helsinki, Finland, 2005 - 2006; Student Advisor, Center of In-service Education, University of Lapland, Finland, 2003; Teacher/Lecturer of Success at work and Human strengths (Educational Psychology), University of Lapland, Lectures held in January 2009, 2010, 2011, 2012; Teacher/Lecturer of Human Strengths, Helsinki Summer University, Helsinki, Finland, 2012; Tutor/educator, SAAVA-project, Utsjoki, Finland, 2004. Her personal research interests are in qualitative methods, positive psychology, and happiness, success, and well-being at work and in life overall.

Dr. Uusiautti is Member of Finnish Educational Research Association, 2012 - and Member of Editorial in five international, peerreviewed journals. 